\title{
Effect of Integrated Nutrient Management on Growth and Yield of Potato (Solanum tuberosum L.)
}

\author{
Ashok Pandit", D.K. Dwivedi, Anup Kumar Choubey, \\ Piyush Kumar Bhargaw and R.K. Raj
}

Department of Agronomy, Dr. Rajendra Prasad Central Agricultural University, Pusa, Samastipur, Bihar - 848125, India

*Corresponding author

\begin{abstract}
A B S T R A C T
A field experiment was conducted during the Rabi season of the year 2017-18 on potato with variety Kufri Ashoka to test the recommended dose of fertilizers (RDF) levels (0, 50,

Keywords

Recommended dose of fertilizers, Vermicompost, Mustard oil cake and Kufri Ashoka

Article Info

Accepted: 24 September 2018 Available Online: 10 October 2018 $75,100,125,150 \%$ ) with two organic manures (vermicompost $5 \mathrm{t} /$ ha and mustard oil cake $2.5 \mathrm{t} / \mathrm{ha}$ ) at research farm of Tirhut college of Agriculture Dholi, Muzaffarpur, Bihar. The experiment was carried out in randomized block design (RBD) with twelve treatments and replicated thrice. The soil of experimental plot was Entisols, sandy loam in texture under low available in $\mathrm{N}, \mathrm{P}$ and $\mathrm{K}$ with $\mathrm{pH}$ 8.3. Among all growth and yield parameters like per cent plant emergence, plant height, number of shoots per plant, number of leaves per plant, dry matter accumulation, and tuber yield were recorded higher with the application of treatment $\mathrm{T}_{11}-150 \% \mathrm{RDF}+5.0 \mathrm{t} / \mathrm{ha}$ vermicompost which was significantly superior over $\mathrm{T}_{1}$ - absolute control, $\mathrm{T}_{2}-100 \% \mathrm{RDF}, \mathrm{T}_{3}-50 \% \mathrm{RDF}+5.0 \mathrm{t} /$ ha vermicompost, $\mathrm{T}_{4}-50 \%$ $\mathrm{RDF}+2.5 \mathrm{t} / \mathrm{ha}$ mustard oil cake, $\mathrm{T}_{5}-75 \% \mathrm{RDF}+5.0 \mathrm{t} /$ ha vermicompost and $\mathrm{T}_{6}-75 \%$ $\mathrm{RDF}+2.5 \mathrm{t} / \mathrm{ha}$ mustard oil cake but was statistically at par with treatments, $\mathrm{T}_{7}-100 \%$ $\mathrm{RDF}+5.0 \mathrm{t} / \mathrm{ha}$ vermicompost, $\mathrm{T}_{8}-100 \% \mathrm{RDF}+2.5 \mathrm{t} / \mathrm{ha}$ mustard oil cake, $\mathrm{T}_{9}-125 \% \mathrm{RDF}$ $+5.0 \mathrm{t} / \mathrm{ha}$ vermicompost, $\mathrm{T}_{10}-125 \% \mathrm{RDF}+2.5 \mathrm{t} / \mathrm{ha}$ mustard oil cake and $\mathrm{T}_{12}-150 \% \mathrm{RDF}$ $+2.5 \mathrm{t} /$ ha mustard oil cake.
\end{abstract}

\section{Introduction}

Potato (Solanum tuberosum L.) is a staple food crop of the world and it ranks next to rice, wheat and maize. It is highly amenable to adjustment and fits well in various cropping systems. Potato is well known for highest food value in the world. It has a high nutritive value, rich in contents like carbohydrates 20.6 $\%$, protein $2.1 \%$, fat $0.3 \%$ and crude fiber 1.1 $\%$. It is the cheapest source of nutrition for the rural mass hence it is called as "poor man's friend". The per capita consumption of potato in India is only $16 \mathrm{~kg}$ per annum but other countries the consumption of potato per capita is quite high thus the use of cereals should be substituted by potato in Indian scenario. It contains five alkaline elements like sodium, potassium, magnesium, calcium and aluminum, hence it acts as a systemic alkaliser to avoid gastric diseases. Boiled tubers when eaten as food without spice and oils, it may be better substitute of rice and bread (Bist and Sharma, 1997). Though, potato has low 
content of fat, while in mineral content, potato produce mineral $1.1 \mathrm{~g}$, phosphorus $75.2 \mathrm{~g}$, calcium $18.8 \mathrm{~g}$, iron $1.30 \mathrm{~g}$, carbohydrate $42.50 \mathrm{~g}$, fibre $752 \mathrm{~g}$, fat $188 \mathrm{~g}$, vitamin C $32 \mathrm{~g}$, vitamin B $2.5 \mathrm{~g} / \mathrm{ha} /$ day, which is much higher than the cereal crops (Yadav et al., 2007). It also contains a good amount of amino acids such as leucine, tryptophan and isoleucine (Paul Khurana and Naik, 2003). It may be served as boiled, steamed, fried, baked, roasted or as ingredient of soups, stews and fries. Potato is main ingredients of vegetarian and non-vegetarian food.

India is the second largest potato producing country in the world after China. In India, during 2015-16, potato is grown over an area of 2.11 million hectare with an annual production of 43.41 million tonnes with an average yield of 20.5 t/ha. Almost $85 \%$ of total production comes from north India plain viz. Uttar Pradesh, West Bengal and Bihar. In world scenario, India has got second position after China with respect to production.

Bihar is the third largest potato producer state of the country, occupying $5 \%$ area of total cultivated land i.e. 0.31 million hectare with a production of 6.34 million tonnes and productivity 19.88 t/ha (Horticultural statistics at a glance 2017). The productivity of potato can be increased and sustained by adoption of integrated nutrient management. Keeping this point in view the present investigation has been carried out.

\section{Materials and Methods}

The field experiment was conducted during Rabi season in year 2017-18 at the farm of Tirhut College of Agriculture, Dholi (Muzaffarpur) which is situated on the southern bank of the river Burhi Gandak at an altitude of 52.18 meter above mean sea level and lies at $25^{\circ} .98^{\prime} \mathrm{N}$ latitude and $85^{\circ} .6^{\prime} \mathrm{E}$ longitude.
Field experimental was laid out in Randomized Block Design with twelve treatments viz., $\mathrm{T}_{1}$ - absolute control, $\mathrm{T}_{2}$ $100 \% \mathrm{RDF}, \mathrm{T}_{3}-50 \% \mathrm{RDF}+5.0 \mathrm{t} / \mathrm{ha}$ vermicompost, $\mathrm{T}_{4}-50 \% \mathrm{RDF}+2.5 \mathrm{t} / \mathrm{ha}$ mustard oil cake, $\mathrm{T}_{5}-75 \% \mathrm{RDF}+5.0 \mathrm{t} / \mathrm{ha}$ vermicompost, $\mathrm{T}_{6}-75 \% \mathrm{RDF}+2.5 \mathrm{t} / \mathrm{ha}$ mustard oil cake, $\mathrm{T}_{7}-100 \% \mathrm{RDF}+5.0 \mathrm{t} / \mathrm{ha}$ vermicompost, $\mathrm{T}_{8}-100 \% \mathrm{RDF}+2.5 \mathrm{t} / \mathrm{ha}$ mustard oil cake, $\mathrm{T}_{9}-125 \% \mathrm{RDF}+5.0 \mathrm{t} / \mathrm{ha}$ vermicompost, $\mathrm{T}_{10}-125 \% \mathrm{RDF}+2.5 \mathrm{t} / \mathrm{ha}$ mustard oil cake, $\mathrm{T}_{11}-150 \% \mathrm{RDF}+5.0$ t/ha vermicompost and $\mathrm{T}_{12}-150 \% \mathrm{RDF}+2.5 \mathrm{t} / \mathrm{ha}$ mustard oil cake and replicated thrice.

\section{Description of experimental variety}

\section{Kufri Ashoka}

Kufri Ashoka developed through clonal selection from the segregating population of the hybrid EM/C-1021 x CP-1468. Central Potato Research Institute, Shimla, released this variety in 1996. Tubers are white, large, oval-long, smooth-skin, fleet eyes and white flesh, grown in north and south Indian hills, parts of Bihar, Gujarat, Karnataka, Madhya Pradesh, Maharashtra, Punjab, Uttar Pradesh and west Bengal. Yield potential is 20-30 t/ha. This variety is moderately tolerant to late blight.

\section{Results and Discussion}

Citation of the data regarding per cent plant emergence at 30 DAP revealed that there was no significant differences among all the treatments, but treatment $\mathrm{T}_{11}-150 \% \mathrm{RDF}+$ 5.0 t/ha vermicompost $(96.38 \%)$ had shown maximum per cent of plant emergence and lowest plant emergence $(92.91 \%)$ at 30 DAP was observed in $\mathrm{T}_{1}$ - absolute control.

The growth parameters of potato were significantly affected due to application of 
organic and inorganic source of nutrients. The maximum plant height and dry matter accumulation was recorded significantly higher under treatment $\mathrm{T}_{11}-150 \% \mathrm{RDF}+5.0$ t/ha vermicompost which was statistically at par with treatments, $\mathrm{T}_{7}-100 \% \mathrm{RDF}+5.0 \mathrm{t} / \mathrm{ha}$ vermicompost, $\mathrm{T}_{8}-100 \% \mathrm{RDF}+2.5 \mathrm{t} / \mathrm{ha}$ mustard oil cake, $\mathrm{T}_{9}-125 \% \mathrm{RDF}+5.0 \mathrm{t} / \mathrm{ha}$ vermicompost, $\mathrm{T}_{10}-125 \% \mathrm{RDF}+2.5 \mathrm{t} / \mathrm{ha}$ mustard oil cake and $\mathrm{T}_{12}-150 \% \mathrm{RDF}+2.5$ t/ha mustard oil cake whereas the minimum plant height and dry matter accumulation were observed under treatment $\mathrm{T}_{1}$ (absolute control) at all the growth stages.. It might be due to more uptake of nitrogen during growth periods, resulted in increased cell size, elongation and enhancement of cell division which ultimately increase the plant height.

The increase in growth parameters might be because of batter photosynthetic area. Since nitrogen is one of the basic minerals associated with synthesis of protoplasm and in primary synthesis of amino acid. The result may be supported by the findings of Singh and Singh (1994), Raghav et al., (2008), Barman et al., (2014 and 2018) (Table 1-3).

Table.1 Plant emergence, plant height $(\mathrm{cm})$ and dry matter accumulation $(\mathrm{g} / \mathrm{plant})$ at different growth stages as affected by different treatments

\begin{tabular}{|c|c|c|c|c|c|c|c|c|c|}
\hline \multirow[t]{2}{*}{ Treatment } & \multirow{2}{*}{$\begin{array}{c}\% \text { plant } \\
\text { emergence } \\
\text { at } 30 \text { DAP }\end{array}$} & \multicolumn{4}{|c|}{ Plant height } & \multicolumn{4}{|c|}{$\begin{array}{c}\text { Dry matter accumulation } \\
\text { (g/plant) }\end{array}$} \\
\hline & & $\begin{array}{c}45 \\
\text { DAP }\end{array}$ & $\begin{array}{c}\text { 60 } \\
\text { DAP }\end{array}$ & $\begin{array}{c}75 \\
\text { DAP }\end{array}$ & $\begin{array}{c}\text { At } \\
\text { harvest }\end{array}$ & $\begin{array}{c}45 \\
\text { DAP }\end{array}$ & $\begin{array}{c}\text { 60 } \\
\text { DAP }\end{array}$ & $\begin{array}{c}75 \\
\text { DAP }\end{array}$ & $\begin{array}{c}\text { At } \\
\text { harvest }\end{array}$ \\
\hline $\mathbf{T}_{1}$ & 92.91 & 20.42 & 24.31 & 31.21 & 31.24 & 16.12 & 21.83 & 32.28 & 44.12 \\
\hline $\mathbf{T}_{2}$ & 95.37 & 28.34 & 32.12 & 41.92 & 42.99 & 22.54 & 29.57 & 51.79 & 62.44 \\
\hline $\mathbf{T}_{3}$ & 94.57 & 25.12 & 29.17 & 36.27 & 36.38 & 20.21 & 25.44 & 45.32 & 56.41 \\
\hline$\overline{T_{4}}$ & 93.89 & 23.80 & 28.21 & 35.41 & 35.47 & 19.81 & 23.67 & 43.61 & 54.01 \\
\hline$T_{5}$ & 94.11 & 27.45 & 31.30 & 40.74 & 40.81 & 21.35 & 28.73 & 50.21 & 60.51 \\
\hline$T_{6}$ & 93.28 & 26.31 & 30.70 & 39.61 & 39.65 & 20.78 & 27.36 & 48.44 & 58.24 \\
\hline $\mathbf{T}_{7}$ & 96.03 & 30.31 & 34.71 & 44.11 & 44.24 & 27.33 & 34.73 & 57.03 & 68.41 \\
\hline$T_{8}$ & 95.87 & 29.81 & 33.54 & 42.41 & 42.48 & 26.96 & 33.63 & 55.12 & 65.93 \\
\hline$T_{9}$ & 96.34 & 31.47 & 35.86 & 46.26 & 46.34 & 28.41 & 35.56 & 59.29 & 70.13 \\
\hline $\mathrm{T}_{10}$ & 95.32 & 31.00 & 34.74 & 44.47 & 44.52 & 27.24 & 34.33 & 57.31 & 67.70 \\
\hline$T_{11}$ & 96.38 & 32.32 & 37.12 & 47.52 & 47.57 & 29.23 & 36.90 & 60.97 & 71.96 \\
\hline$\overline{T_{12}}$ & 94.93 & 31.96 & 36.01 & 45.64 & 45.70 & 27.69 & 35.19 & 58.36 & 69.30 \\
\hline S Em ( $( \pm)$ & 3.37 & 0.854 & 1.027 & 1.459 & 1.482 & 0.891 & 1.104 & 1.83 & 2.22 \\
\hline $\begin{array}{l}\text { CD } \\
(p=0.05)\end{array}$ & 9.88 & 2.506 & 3.014 & 4.280 & 4.345 & 2.614 & 3.238 & 5.36 & 6.50 \\
\hline
\end{tabular}


Table.2 Number of shoots and leaves per plant at different growth stages as Affected by different treatments

\begin{tabular}{|c|c|c|c|c|c|c|c|c|}
\hline \multirow[t]{2}{*}{ Treatment } & \multicolumn{4}{|c|}{ Number of Shoots } & \multicolumn{4}{|c|}{ Number of leaves } \\
\hline & $\begin{array}{c}45 \\
\text { DAP }\end{array}$ & $\begin{array}{c}60 \\
\text { DAP }\end{array}$ & $\begin{array}{c}75 \\
\text { DAP }\end{array}$ & $\begin{array}{c}\text { At } \\
\text { harvest }\end{array}$ & $\begin{array}{c}45 \\
\text { DAP }\end{array}$ & $\begin{array}{c}60 \\
\text { DAP }\end{array}$ & $\begin{array}{c}75 \\
\text { DAP }\end{array}$ & $\begin{array}{c}\text { At } \\
\text { harvest }\end{array}$ \\
\hline $\mathbf{T}_{1}$ & 2.32 & 3.12 & 3.22 & 3.22 & 30.15 & 35.21 & 38.37 & 23.26 \\
\hline$T_{2}$ & 4.03 & 4.98 & 5.11 & 5.11 & 39.23 & 45.31 & 49.39 & 32.18 \\
\hline$T_{3}$ & 2.89 & 3.53 & 3.65 & 3.65 & 34.00 & 39.45 & 43.68 & 27.36 \\
\hline$T_{4}$ & 2.71 & 3.40 & 3.54 & 3.54 & 33.43 & 39.31 & 43.21 & 27.11 \\
\hline $\mathrm{T}_{5}$ & 3.87 & 4.71 & 4.82 & 4.82 & 38.06 & 45.74 & 49.50 & 32.76 \\
\hline$T_{6}$ & 3.65 & 4.56 & 4.68 & 4.68 & 36.44 & 42.51 & 46.62 & 30.20 \\
\hline $\mathrm{T}_{7}$ & 4.61 & 5.68 & 5.79 & 5.79 & 44.19 & 50.97 & 55.01 & 37.32 \\
\hline$T_{8}$ & 4.52 & 5.48 & 5.59 & 5.59 & 42.58 & 48.22 & 51.31 & 34.10 \\
\hline$T_{9}$ & 4.81 & 5.73 & 5.84 & 5.84 & 46.35 & 52.46 & 55.89 & 37.78 \\
\hline$T_{10}$ & 4.75 & 5.61 & 5.80 & 5.80 & 44.89 & 51.37 & 54.96 & 36.91 \\
\hline$T_{11}$ & 4.94 & 5.80 & 5.92 & 5.92 & 47.15 & 53.67 & 57.77 & 38.77 \\
\hline$T_{12}$ & 4.88 & 5.77 & 5.90 & 5.90 & 46.99 & 53.11 & 56.83 & 38.29 \\
\hline S Em $( \pm)$ & 0.18 & 0.20 & 0.21 & 0.21 & 1.51 & 1.64 & 1.82 & 1.14 \\
\hline CD $(p=0.05)$ & 0.52 & 0.60 & 0.60 & 0.60 & 4.42 & 4.82 & 5.35 & $\mathbf{3 . 3 3}$ \\
\hline
\end{tabular}

Table.3 Effect of different treatments on fresh tuber and vine yield and harvest index of potato

\begin{tabular}{|c|c|c|c|}
\hline Treatments & Tuber yield (q/ha) & Yield of Vine (q/ha) & Harvest index (\%) \\
\hline $\mathrm{T}_{1}$ & 111.28 & 72.20 & 60.65 \\
\hline $\mathrm{T}_{2}$ & 233.30 & 106.69 & 68.62 \\
\hline $\mathrm{T}_{3}$ & 210.24 & 100.68 & 67.62 \\
\hline $\mathrm{T}_{4}$ & 207.02 & 99.45 & 67.55 \\
\hline $\mathrm{T}_{5}$ & 237.23 & 106.48 & 69.02 \\
\hline $\mathrm{T}_{6}$ & 235.58 & 105.59 & 69.05 \\
\hline $\mathrm{T}_{7}$ & 262.00 & 115.96 & 69.32 \\
\hline $\mathrm{T}_{8}$ & 259.67 & 116.72 & 68.99 \\
\hline $\mathrm{T}_{9}$ & 272.45 & 117.26 & 69.91 \\
\hline $\mathrm{T}_{10}$ & 269.23 & 117.15 & 69.68 \\
\hline $\mathrm{T}_{11}$ & 276.15 & 118.45 & 69.97 \\
\hline $\mathrm{T}_{12}$ & 273.87 & 118.21 & 69.85 \\
\hline $\mathrm{S} \mathrm{Em}( \pm)$ & $\mathbf{8 . 2 4}$ & $\mathbf{3 . 4 8}$ & $\mathbf{1 . 7 0}$ \\
\hline $\mathrm{CD}(\boldsymbol{p}=\mathbf{0 . 0 5}$ & $\mathbf{2 4 . 1 6}$ & $\mathbf{1 0 . 1 9}$ & $\mathbf{4 . 9 7}$ \\
\hline
\end{tabular}

Number of shoots and no of leaves per plant significantly influences by the application of integrated nutrient management. Application of treatment $\mathrm{T}_{11}(150 \% \mathrm{RDF}+5.0 \mathrm{t} / \mathrm{ha}$ vermicompost) recorded higher number of shoots and leaves which was significantly superior over rest of the treatment but was statistically at par with treatments $\mathrm{T}_{7} \mathrm{~T}_{8} \mathrm{~T}_{9}$ $T_{10} T_{11}$ and $T_{12}$ whereas the minimum number of shoots and leaves was recorded under 
treatment $\mathrm{T}_{1}$ (absolute control) at all the successive growth stages. The application of organic manure improving soil structure, enhance water holding capacity of soil and microbial activity in the soil. This might be due to nutrients were recycled into the soil lead to increase the number of shoots and leaves which may have resulted in increased synthesis of carbohydrates utilized in building up of new cells.

Nitrogen increased the chlorophyll synthesis resulting in more area of photosynthesis and net assimilation. The leaves per plant decreased after the 90 days of planting, irrespective of the treatment due to senescence of leaves. This result is in accordance with the finding of Debasish et al., (2001), Banjare (2012) and Etemad, B. and Sarajuoghi, M. (2012).

\section{Tuber and vine yield}

The highest tuber (276.15 q/ha) and vine yield $(118.45 \mathrm{q} / \mathrm{ha})$ was recorded with $150 \%$ recommended dose of fertilizer along with vermicompost which was significantly higher than other treatments but was at par with treatments $\mathrm{T}_{7} \mathrm{~T}_{8} \mathrm{~T}_{9} \mathrm{~T}_{10} \mathrm{~T}_{11}$ and $\mathrm{T}_{12}$. The maximum harvesting index (69.97) was also recorded under treatment $\mathrm{T}_{11}(150 \% \mathrm{RDF}+$ $5.0 \mathrm{t} /$ ha vermicompost) whereas the minimum harvesting index (60.65) was observed under treatment $\mathrm{T}_{1}$ (absolute control). Higher yield obtained with application of higher dose of fertilizers (NPK) might be due to positive response of potato crop to the nutrients like nitrogen, phosphorus and potash. The beneficial response of organic manure to increase the crop yield might also be attributed to the availability of sufficient amounts of plant nutrients throughout the growth period and especially at critical growth periods of crops resulting it's better uptake, plant Vigour and superior yield attributes. These results are in conformity with the finding of Sarkar et al., (2011), Banjare (2012), Patel (2013) and Kumar et al., (2017).

\section{References}

Banjare, S. 2012. Study on the effect of different levels of nitrogen in the form of urea on potato production. $M$. Sc. (Ag.) Thesis IGKV, Raipur. pp. 82-83.

Barman, K. S., Kumar, A., Kasera, S. and Ram, B. 2018. Integrated nutrient management in potato (Solanum tuberosum) cv. Kufri Ashoka. Journal of Pharmacognosy and Phytochemistry, SP1:1936-1938.

Barman, K.S., Ram, B. and. Verma, R.B. 2014. Effect of Integrated Nutrient Management on Growth and Tuber Yield of Potato (Solanum tuberosum) cv. Kufri Ashoka. Trends in biosciences. 7(9): 815-817.

Bist, B.S. and Sharma, H.C. 1997. Potato Statistics - India and the world. Revised Edition.

Debasish, B., Sharma, B.N. and Saikia, M. 2001. Effect of phosphorous on growth and tuber yield of potato raised from TPS transplants. Journal of Agricultural Science Society of North-East India.14 (2): 236-239.

Etemad, B. and Sarajuoghi, M. 2012. Study of the effect of different levels and application timing of nitrogen fertilizer on yield and number of potato tuber. Annals of Biological Research. 3(3): 1385-1387.

Horticultural Statistics at a Glance 2017 Database (Visit us at: www.agricoop.nic.in).

Khurana, S.M.P. and Naik, P.S. 2003. The Potato Production and Utilization in Sub - tropics region. Mehta Publication. New Delhi, India pp 1-14.

Kumar, P., Kumar, A., Kumar, N., Ahamad, A. and Verma, M. K. 2017. Effect of 
integrated nutrient management on productivity and nutrients availability of potato. International Journal of Current Microbiology and Applied Sciences. 6(3): 1429-1436.

Patel, B. 2013. Effect of different levels of NPK on growth, development and yield of potato cv. Kufri Ashoka under chhattisgarh plain condition. $M . S c .(A g)$ Thesis IGKV, Raipur. pp. 70-71.

Raghav, M., Kumar T. and Kamal, S. 2008. Effect of organic sources on growth, yield and quality of potato. Annals of Horticulture. 1(1): 67-70

Sarkar, A., Sarkar, S. and Zaman, A. 2011. Growth and yield of potato as influenced by combination of organic manures and inorganic fertilizers. Potato Journal. 38(1): 78-80.
Sarkar, A., Sarkar, S. and Zaman, A. and Devi, W.P. 2011. Productivity and profitability of different cultivars of potato (Solanum tuberosum L.) as affected by organic and inorganic sources of nutrients. Indian Journal of Agronomy. 56(2): 156-163.

Singh, T.P., Singh, R.P. 1994. Effect of rates and methods of nitrogen application on biomass and tuber production of potato. Crop Res. 8(3): 637-639.

Yadav A.R., Guha, M., Reddy, S.Y., Tharanbathan, R.N. and Ramteke, R.S. 2007. Physical properties of acetylated and enzyme modified potato and sweet potato flours. Journal of Food Science. 72: 249-253.

\section{How to cite this article:}

Ashok Pandit, D.K. Dwivedi, Anup Kumar Choubey, Piyush Kumar Bhargaw and Raj, R.K. 2018. Effect of Integrated Nutrient Management on Growth and Yield of Potato (Solanum tuberosum L.). Int.J.Curr.Microbiol.App.Sci. 7(10): 3326-3331. doi: https://doi.org/10.20546/ijcmas.2018.710.385 